\title{
ANALISIS GAYA KEPEMEMIMPINAN KEPALA KANTOR URUSAN AGAMA KECAMATAN MURUNG KABUPATEN MURUNG RAYA
}

\author{
Mitra $^{\text {l* }}$ \\ Mirja ${ }^{2 *}$ \\ I* Penyuluh Agama Islam Non PNS Kantor Kementerian Agama Kabupaten Murung Raya \\ Kalimantan Tengah, Indonesia \\ Email: aiysayyidhan@gmail.com \\ $2^{2}$ Guru ASN Pemkab Murung Raya \\ Email: mirja.tuhup86@gmail.com
}

\section{Abstrak}

Seorang leader dapat mempengaruhi moral dan kepuasan kerja, keamanan, kualitas kehidupan kerja dan terutama tingkat prestasi suatu organisasi, pimpinan juga memainkan peranan penting dalam membantu kelompok, organisasi atau masyarakat untuk mencapai tujuan mereka. Dengan berjiwa pemimpin manusia akan dapat mengelola diri, kelompok dan lingkungan dengan baik, khususnya dalam penanggulangan masalah yang relative pelik dan sulit sehingga disinilah dituntut kearifan seorang pemimpin untuk menentukan problem solving yang tepat guna menyelesaikan masalah tersebut.

Penelitian merupakan penelitian ekploratif melalui pendekatan kualititatif yang sifatnya dekriptif. Pendekatan tersebut dipilih karena pengamatan ini berusaha memperoleh pandangan baru tentang suatu gejala atau untuk mendapat gambaran ciri-ciri individu atau kelompok. Berdasarkan analisis data penelitian bahwa Kepala Kantor Urusan Agama Kecamatan Murung Kabupaten Murung Raya menggunakan gaya Laissez Faire. Sedangkan Gaya kepemimpinan Otokrtatis dan Demokratis hanya sedikit saja yang ada, meskipun tidak menerapkan gaya Otokratis, akan tetapi paling tidak sifat kharisma harus ada pada diri seorang pemimpin sehingga kedepannya karyawan/pegawai yang lainnya merasa bahwa pemimpinnya layak untuk di berikan apresiasi dalam sikap dan sifat segan terhadap pimpinan oleh pegawailkaryawannya, oleh karena itu penting untuk menjalin kerjasama yang solid dengan bawahannya supaya assesment yang telah di planing dapat berjalan efektif dan efisien.

Kata Kunci: Gaya, Kepemimpinan, Kepala KUA Murung

\begin{abstract}
A leader can affect morale and job satisfaction, security, quality of work life and especially the level of achievement of an organization, leaders also play an important role in helping groups, organizations or society to achieve their goals. With the spirit of a human leader, he will be able to manage himself, the group and the environment well, especially in overcoming relatively complex and difficult problems, so this is where the wisdom of a leader is required to determine the right problem solving in order to solve these problems.

This research is an exploratory research through a qualitative approach that is descriptive in nature. This approach was chosen because this observation seeks to gain a new view of a phenomenon or to get a picture of the characteristics of an individual or group. Based on the analysis of research data, the Head of the Office of Religious Affairs in Murung District, Murung Raya Regency, uses the Laissez Faire style. Meanwhile, there are only a few autocratic and democratic leadership styles, even though they do not apply the autocratic style, but at least the charismatic nature must exist in a leader so that in the future employees / other employees feel that the leader deserves to be given appreciation in an attitude and reluctance. towards the leadership by employees / employees, therefore it is important to establish solid cooperation with subordinates so that the assessments that have been planned can run effectively and efficiently.
\end{abstract}

Keywords: Style, Leadership, The Head of KUA Murung 


\section{PENDAHULUAN}

Era globalisasi dunia usaha ditandai dengan terbukanya persaingan yang ketat di segala bidang, termasuk pada jasa pelayanan di Kantor Urusan Agama Kecamatan Murung Kabupaten Murung Raya. Permasalahan ini merupakan sebuah tantangan dalam kerangka pembangunan sumber daya bangsa indonesia. Kita dituntut untk mempu menghadapi tantangan tersebut dengan meggali lebih dalam lagi, menggasah kemampuan skill agar memiliki keahlian pada lini sendi kehidupan supaya mampu survive dengan tantangan zaman di era industri 4.0

Menurut Susilo Martoyo (2000: 3-4) bahwa sumber daya manusia merupakan faktor yang sangat penting dalam sebuah organisasi baik organisasi dalam skala besar maupun kecil. Pengelolaan sumber daya manusia merupakan metode atau cara yang digunakan oleh atasan kepada bawahannya untuk membuat perencanaan, pengorganisasian, pelaksanaan serta pengevaluasian. Pengertian fungsi manajemen sumber daya manusia dilaksanakan untuk mengelola semua komponen kegiatan yang ada dalam suatu instansi ataupun organisasi perusahaan. Supaya visi dan misi tersebut dapat dicapai, diperlukan gaya kepemimpinan seorang pemimpin untuk mempengaruhi bawahannya, hal ini merupakan norma perilaku yang berguna ketika seorang leader mencoba untuk merubah perilaku bawahannya, masing- masing gaya tersebut memiliki keunggulan dan kelemahan. Ketika seorang pemimpin menggunakan gaya kepemimpinannya sesuai dengan habbituation yang telah melekat pada dirinya maka akan nampak muncul kepermukaan model kepemimpinannya. Maka dari itu, skill seorang pemimpin yang mumpuni dibutuhkan untuk bisa menjawab tantangan zaman di saat ini sesuai dengan gaya kepemimpinan yang melekat pada dirinya.

Kementerian Agama mempunyai kedudukan strategis ditengah masyarakat karena peran serta Kantor Urusan Agama sebagai lidding sector yang berupaya memberikan pelayanan di tengah masyarakat. Oleh karena diperlukan sumber daya manusia pada KUA Kecamatan yang professional, kreatif, proaktif dan produktif, serta mempunyai semangat pengabdian yang tinggi dengan kesadaran dan tanggung jawab yang besar sebagai abdi negara untuk melayani masyarakat, sehingga dari hal itu diharapkan dapat mewujudkan di Kantor Urusan Agama Kecamatan Murung Kabupaten Murung Raya kondisi lingkungan kerja yang selalu berkembang dan berubah harus tetap dipantau untuk melihat kecendrungan dan mengantisipasi perubahan-perubahan yang mungkin terjadi pada lingkungan, semua itu dimulai dari pemimpin organisasi atau Kepala KUA ketika menyusun program kerja, sebagai hasil penerapan gaya kepemimpinan yang disukai bawahanya. Keberhasilan kepemimpinan dimana semua unsur manajemen itu harus mengarah pada tujuan dan nilai-nilai yang telah disepakati oleh kelompok atau organisasi dalam menghadapi tantangan atau mencapai tujuan dari Kantor Urusan Agama yang dipimpinnya.

\section{Kepala Kantor Urusan Agama} Kecamatan Murung Kabupaten Murung Raya dalam menjalankan tugas kepemimpinannya juga harus mampu melakukan komunikasi yang efektif terhadap bawahannya terutama bagi pimpinan unit atau kepala bidang dan dan karyawan honorer pada Kantor Urusan Agama Kecamatan Murung Kabupaten Murung Raya dan mampu mengkomunikasikan program- program kerja KUA Murung yang akan dilaksanakan para bawahanya. Sebagai pemimpin, kepala KUA 
Murung harus mampu menciptakan budaya kerja yang kondusif, saling mendukung satu sama lain, saling menguatkan energi organisasi, untuk memberikan pelayanan optimal kepada masyarakat Kabupaten Murung Raya khususnya di lingkup wilayah kerja KUA Kecamatan Murung.

Berdasarkan Peraturan Menteri Agama RI No.I3 Tahun 2012 tentang Organisasi dan tata kerja Instansi Vertikal Kementerian Agama Provinsi Kalimantan Tengah pasal 6 dinyatakan bahwa Kantor Kementerian Agama Kabupaten/kota, berada dibawah dan tanggung jawab Kepala Kantor Wilayah Kementerian Agama.

Kantor Urusan Agama Kecamatan Murung menyelenggarakan fungsi:

I. Melakukan penginputan statistik dan dokumentasi kegiatan di lingkup yuridis Kecamatan Murung

2 Mengarsipkan surat-menyurat yang masuk maupun keluar, serta pengetikan di Kantor Urusan Agama Kecamatan.

3. Melakukan pencatatan atau pendaftaran nikah bagi catin secara online, biaya nikah di luar kantor, biaya rujuk, pembianaa mesjid, ZISWAF, ibadah sosial, kependudukan dan pengembangan keluarga sakinah.

Berdasarkan tupoksi tersebut KUA Kecamatan Murung dituntuk untuk bekerja secara efektif dalam melayani masyarakat. Apabila kinerja pegawai pada Kantor Urusan Agama Kecamatan rendah, maka hal ini akan mengakibatkan kerugian baik dari sisi pemerintah, maupun kerugian dari sisi diri pribadi setiap pegawai Negeri Sipil yang ada didalamnya.

Dari uraian tugas pokok dan fungsi tersebut juga dapat disadari peranan manusia dalam hal ini pegawai Negeri Sipil amatlah penting, maka untuk suksesnya suatu organisasi didalam mencapai tujuan organisasi salah satu faktornya yaitu skill pimpinan dalam berusaha meningkatkan kinerja bawahannnya.

Kemampuan Kepala KUA Kecamatan Murung dalam melaksanakan dalam melaksanakan tugas kepemimpinannya harus melakukan perencanaan program kerja yang efektif karena dengan pelaksanaan fungsi perencanaan efektif merupakan sesuatu yang harus ada demi berjalannya roda organisasi. Sehubungan dengan pemikiran tersebut, maka peneliti tertarik untuk mengetahui gaya kepemimpinan yang digunakan oleh Kepala KUA kecamatan Murung Kabupaten Murung Raya Provinsi Kalimantan Tengah. Pengamatan tersebut penting untuk dilakukan demi peningkatan pelaksanaan program dan menciptakan kedisiplinan kerja pegawainya dan menciptakan komunikasi yang baik antara pimpinan dan bawahan pada Kantor Urusan Agama Kecamatan Murung. Karena kami melihat tingkat kedisiplinan pegawai pada Kantor Urusan Agama Kecamatan Murung Kabupaten Murung Raya belum mampu dikontrol dengan baik seperti pelaksanaan program pelayanan kepada catin (calon Pengantin) yang hendak mendaftarkan pernikahannya di kantor KUA Murung, sehingga peranan pimpinan sangat diperlukan. Dipilihnya KUA Murung objek yang akan kami analisa karena KUA Murung tersebut belum menempatkan peraturan kedisiplinan terhadap pegawai dan juga belum baiknya komunikasi yang efektif antara pimpinan dan bawahannya, sehingga dalam melaksanakan setiap program KUA Murung berupa pelayanan kepada masyarakat menjadi terhambat seperti kasus terlambatnya buku nikah untuk di keluarkan dan segera di berikan kepada pengantin yang telah menikah. Oleh karena itu supaya tujuan itu dapat terwujud diperlukan sosok pemimpin yang handal, yang mampu memanajemen dengan baik instansinya. 
Dari uraian mengenai latar belakang masalah, pengamatan ini dapat dirumuskan masalahnya yaitu Bagaimana Gaya dan Tipe Kepemimpinan Kepala Kantor Urusan Agama Kecamatan Murung Kabupaten Murung Raya. Adapun tujuan pengamatan ini adalah untuk menganalisis dan mendeskripsikan gaya dan tipe kepemimpinan Kepala Kantor Urusan Agama Kecamatan Murung Kabupaten Murung Raya.

\section{KONSEP TEORI}

Teori kepemimpinan berasal dari kata pimpin yang artinya bimbing atau tuntutan. Harbani Pasalong (2008:I). berdasarkan kata pimpin menghasilkan kata kerja "memimpin" yang maknanya adalah membimbing atau menuntun, jika dimaknai sebagai kata benda maka kata memimpin bermakna orang yang melakukan bimbingan atau orang yang menuntun. Sedangkan kepemimpinan adalah skill pemimpin yang berguna untuk mencapai visi dan misi organisasi atau instansinya. dari berbagai studi literatur yang membahas tentang kepemimpinan sehingga muncul istilah yang sama dengan hal tersebut yaitu pimpinan dan pemimpin. Oleh karena itu, perlu dikemukakan beberapa pengertian kedua konsep tersebut untuk menyamakan persepsi dan interprestasi terhadap suatu kontek yang dibahas.

Winardi (2000:79) bahwa gaya kepemimpinan menurut Ralph White dan Ronald Lippitt yaitu sebagai berikut:

1. Gaya otoriter. Gaya ini merupakan gaya kepemimpinan di mana pemimpin otokratis dengan mengetahui apa saja yang diinginkan langsung melakukan perintah kepada bawahannya tanpa ada sanggahan maupun mufakat dari orang lain

2. Gaya demokratik yaitu gaya kepemimpinan yang dikenal pula denga gaya kepemimpinan partisipatif yang beranggapan bahwa para anggota organisasi yang ambil bagian secara pribadi dalam proses pengambilan keputusan akan memiliki komitmen, akan memiliki tekad yang kuat untuk menggapai tujuan instansi atau organisasinya.

3. Gaya Laissez Faire yaitu gaya kepemimpinan yang bebas. Gaya ini berasumsi bahwa tupoksi bawahannya diberi keleluasaan dalam mengambil metode mereka masing-masing dalam menggapai tujuan instansi atau organisasi.

Terkait syarat kepemimpinan biasanya dikonotasikan dengan makna kemampuan, skill, kewibawaan, kekuasaan, dll. Teori dasar dari seorang pemimpin menurut Sondang P. Siagian (2003:29) bahwa pada dasarnya dapat diterangkan melalui tiga aliran teori sebagai berikut:

\section{Teori Genetis atau teori keturunan}

Penganut paham aliran ini menjelaskan bahwa karena telah dilahirkan dengan bakat pemimpin maka orang itu akan menjadi pemimpin. Inti dari teori ini menyatakan bahwa leader are born and not made yang artinya seorang pemimpin itu dilahirkan sebagai bakat dan bukannya dibuat, hal ini menjelaskan dalam kondisi apapun karena sudah kodratnya menjadi pimpinan maka nantipun ia akan tetap menjadi pemimpin.

\section{Teori Sosial}

Maksud dari aliran teori sosial ini adalah pemipin itu di buat, didik bukan karena faktor kodratnya ia menjadi pemimpin lalu manjadi pemimpin. Oleh karena itu teori ini merupakan kebalikan inti teori keturunan seperti diatas. Menurut paham teori ini bahwa jika seorang diberikan pendidikan dan 
pengalaman maka ia bisa saja menjadi pemimpin.

\section{Teori Ekologis}

Munculnya teori ini karena faham berbeda dengan kedua teori diatas, yang kesimpulannya bahwa pemimpin hanya akan berhasil apabila telah memiliki bakat pemimpin lalu skill itu diasah melalui pendidikan yang terarah serta pengalaman yang berkesinambungan, sekilas teori ini merupakan sitesis dari kedua teori diaatas.

Menurut Pasolong (2008:30) bahwa fungsi kepemimpinan birokrasi dapat dijelaskan sebagai berikut:

I. Fungsi perintah. Yakni fungsi yang bersifat satu arah kepada bawahan yang dipimpinnya. Sebagai kumunikator seorang pimpinan bisa menentukan apa saja, dimana saja, bagaiamana serta kapan melakukan perintah kepada bawahannya, hal ini tidak akan berguna jika pimpinan tidak memiliki skill untuk melakukannya dan tentunya jika fungsi ini tidak berguna maka bertolak belakang dengan teori kepemimpinan, dimana seorang pemimpin itu diharuskan mampu untuk mempengaruhi dan menggerakkan bawahannya.

2. Fungsi konsultatif. Yakni fungsi kepemimpinan yang bersifat dua arah kepada yang dipimpinnya, meskipun pelaksanaan sangat tergantung pada pihak pemimpin. Jadi fungsi seorang pemimpin dalam hal ini adalah sebagai sarana bimbingan, dalam mengambil keputusan harus berkosultasi dengan berbagai pihak dengan mempertimbangkan saran dan masukan sehingga dengan hal ini diharapkan keputusan bisa mendapatkan dukungan dari berbagai elemen

3. Fungsi partisipatif. Yakni fungsi kepemimpinan dua arah. Maksudnya antara pimpinan dan bawahan terlaksananya hubungan yang efektif. Pada fungsi ini, pimpinan akan berupaya melibatkan semua elemen yang ada di bawahnya untuk ikut turut serta mengambil bagiaan dalam sebuah kegiatan

4. Fungsi delegasi. Yakni fungsi pemimpin yang mendelegasikan wewenang untuk membuat, menetapkan, dan atau melaksanakan keputusan, baik melalui persetujuan maupun tanpa persetujuan pimpinan. Dalam hal ini pimpinan mempertimbangkan orang yang dapat dipercayanya untuk bisa mengambil tugas dan fungsinya.

\section{PEMBAHASAN DAN HASIL}

Jenis penelitian yang digunakan dalam objek pengamatan kami ini adalah pengamatan deskriptif dengan pendekatan kualitatif, pendekatan tersebut dipilih karena pengamatan ini berusaha memperoleh pandangan baru tentang suatu gejala atau untuk mendapat gambaran ciri-ciri individu atau kelompok. Sebagai landasan teori menurut Moleong (2005:14) yang mengartikan dan memahami metode kualitatif sebagai prosedur pengamatan yang mengahasilkan data dekriptif berupa kata-kata tertulis atau lisan dari orang-orang yang dan perilaku yang dapat diamati.

Dalam pengamatan deskriptif ini berusaha menjawab pertanyaan yang berkaitan dengan analisis gaya kepemimpinan Kepala KUA Murung. Merujuk pada teori yang disampaikan Moelong (2005:23) di atas, maka analisa pengamatan ini dengan mengunakan metode kualitatif dengan pendekatan deskriptif sangat sesuai untuk memahami dan mengambarkan fenomena sosial yang terjadi pada Kantor Urusan Agama Kecamatan Murung. kami berkeyakinan bahwa dengan pengamatan kualitatif akan diperoleh informasi yang selanjutnya dengan informasi tersebut kami bisa membuat 


interprestasi dan analisis untuk
mendiskripsikan gaya kepemimpinan Kepala Kantor Urusan Agama Kecamatan Murung.

Adapun pengumpulan data dipergunakan dalam analisa ini adalah:

1. Observasi yaitu pengumpulan data dengan cara melihat dengan dekat keadaan obyek pengamatan atau mengamati langsung terhadap obyek yang diteliti. Untuk mengetahui aktivitas dari obyek pengamatan dan peristiwa-peristiwa yang mendukung tujuan pengamatan.

2. Wawancara (Interview) yaitu pengumpulan data dimana peneliti secara langsung mengajukan pertanyaan terhadap narasumber untuk memperoleh data atau informasi yang berkaitan dengan kajian pengamatan. Wawancara dilakukan untuk menggali data secara mendalam tentang pertanyaan-pertanyaan yang ada dalam fokus pengamatan.

Berdasarkan teori kepemimpinan diatas mengemukakan bahwa kepemimpinan adalah suatu cara pemimpin untuk mempengaruhi bawahannya maka terdapat faktor penentu gaya kepemimpinan seorang pimpinan agar dapat menggapai tujuan organisasi, jika hal ini tidak didapati pada jiwa seorang pimpinan maka yang akan terjadi misalnya ketidak puasan pegawai terhadap cara pimpinan, munculnya konflik intern, dan lain sebagainya.

Masa Kepemimpinan Kepala Kantor Urusan Agama Kecamatan Murung Kabupaten Murung Raya yang baru menjabat sejak Januari 2020 sampai sekarang seharusnya mengupayakan memberikan contoh yang baik kepada para pegawai misalnya dalam kedisiplinan pada pagi hari bisa dilaksanakan kegiatan apel pagi di halaman kantor. tetapi pada kenyataanya, beliau (Kepala KUA Kecamatan Murung) berdasarakan hasil obeservasi kami belum berupaya untuk bisa memimpin apel pagi 28 dengan memberikan arahan-arahan dan tugastugas yang harus dilaksanakan dengan baik dan penuh tanggung jawab Kemudian seorang pimpinan seharusnya memiliki kharisma dan watak yang kuat agar dapat mempengaruhi bawahannya, dan hal itu tidak dimiliki oleh kepala KUA Murung pada masa sekarang. Hal itu sangat berpengaruh terhadap personil pegawai yang ada di KUA Murung baik itu yang PNS ataupun yang Honorer dimana kehadiran pegawai pada waktu pagi hari tidak menentu atau tidak konsisten. Serta di beberapa tupoksi job deskription dari pegawai Honorer dan PNS belum terlaksana dengan baik dan solid karena dalam hal ini pembinaan maupun evaluasi sampai saat sekarang belum dilakukan oleh kepala KUA Kecamatan Murung.

\section{Pencapaian korelasi teori dan data pengamatan}

\section{Gaya Otokratis}

Kepala KUA Kecamatan Murung selalu memerintahkan bawahanya untuk melaksanakan semua kegiatan sesuai standar operasional prosedur yang berlaku, dan beliau selalu menegaskan untuk tidak melakukan kegiatan fiktif dan mark-up anggaran. Kepala KUA dalam hal-hal tertentu terkadan biasa memberikan perintah, tetapi pada realita yang saya saksikan terkadang perintah dari Kepala KUA Kecamatan Murung tidak dilaksanakan atau dibantah oleh bawahannya, walaupun pada kenyataannya hal itu bermaksud baik, hal ini belum sesuai dengan gaya kepemimpinan otoriter, karena dalam keadaan-keadaan tertentu bapak Kepala KUA Kecamatan Murung seharusnya bersikap otokratis dalam kepemimpinannya. gaya kepemimpinan otoriter baik juga untuk diterapkan Pada Kantor Urusan Agama Kecamatan 
Murung Kabupaten Murung Raya agar setiap program dapat berjalan secara efektif dan efisien dengan mendisiplinkan pegawai, memotivasi agar bertanggung jawab dengan tugas dan fungsinya.

\section{Gaya Demokratis}

Implementasi gaya kepemimpinan ini mengharapkan tindakan yang objektif terhadap permasalahan yang dihadapi, dengan rasa kepemilikan terhadap suatu instansi serta terbinanya hubungan yang baik antar lini akan terjadi perilaku yang bejalan harmoni sehingga setiap keputusan yang dimusyawarahkan setiap individu dapan memberikan saran dan masukan sehingga tingkat permasalahan yang muncul akan lebih sedikit terjadi.

Kepala Kantor Urusan Agama Kecamatan Murung Kabupaten Murung Raya lebih cenderung menerapkan gaya kepemimpinan Demokratis dibandingkan dengan Otokrasi, hal ini dapat dilihat dengan kecenderungan pimpinan yang suka mendengarkan pendapat dari orang lain, suka melakukan obrolan santai dengan pegawainya meskipun belum melakukan musyawarah atau rapat yang secara resmi, suka bekerjasama dalam beberapa hal kecil, sehingga pada beberapa kebijakan dirumuskan hanya melalui obrolan santai tersebut bukan melalui musyawarah/rapat resmi karena sampai saat ini hal tersebut belum dilakukan.

\section{Gaya Laissez Faire}

Kepala KUA Murung juga menggunakan gaya laissez faire atau kendali bebas, hal ini ditunjukkan dengan mempercayakan kepada bawahannya untuk kebebasan dalam menjalankan sikap dan tanggung jawab pada pekerjaan yang dilakukannya. Biasanya pimpinan hanya melihat-lihat atau memantau dari kejauhan tanpa adanya tindakan yang berupa bimbingan. Pemimpin Laissez Faire memposisikan dirinya sebagai fasilitator.

Kepala KUA Kecamatan Murung menurut analisa kami menerapkan gaya Laissez Faire, hal ini dibuktikan dengan beberapa sikap yang kami amati beliau (Kepala KUA Kecamatan Murung) memberikan kebebasan kepada pegawai/karyawan dalam beraktifitas di Kantor serta memberikan kebebasan dalam mengembangkan skill dalam melayani tamu yang datang, juga memberikan kebebasan mengasah kemampuan untuk menguasai IT kepada siapa saja hal ini berguna supaya dalam melayani Catin yang hendak menikah supaya terdaftar melalui Online di web. Keseluruhan hal tersebut pada analisa kami semua karyawan/pegawai KUA belum mendapatkannya sejak sebelum pergantian masa jabatan Kepala KUA Murung yang baru.

Sebagaimana mengutip pendapat Asyarie Abbas dan Marwito (20I5:47) bahwa peran seorang pemimpin dalam suatu organisasi hendaknya selalu ada untuk pegawainya, tidak hanya pada saat memberikan intruksi, dan tugas-tugas saja, namun pada saat ada waktu luang pun dapat menjadi sebuah kesempatan bagi pimpinan untuk melakukan pendekatan lebih dalam lagi terhadap pegawainya, hal demikian dapat menjadikan suatu hubungan antara pimpinan dan bawahannya menjadi tidak kaku dalam suatu organisasi.

\section{KESIMPULAN DAN REKOMENDASI}

\section{Kesimpulan}

Berdasarkan hasil analisis data yang 
diperoleh dari hasil observasi dan wawancara tentang pengamatan terhadap Analisis Gaya Kepemimpinan Kepala KUA Murung, maka kami mengambil kesimpulan bahwa Kepala Kantor Urusan Agama Kecamatan Murung Kabupaten Murung Raya menggunakan gaya Laissez Faire. Sedangkan Gaya kepemimpinan Otokrtatis dan Demokratis belum sepenuhnya ada pada sikap dan sifat beliau (Kepala KUA Kecamatan Murung) yang sekarang.

2. Kepala KUA Murung dalam hal gaya kepemimpinan seharusnya meskipun tidak menerapkan gaya Otokratis, akan tetapi paling tidak sifat kharisma harus ada pada diri beliau sehingga kedepannya karyawan/pegawai yang lainnya merasa bahwa beliau layak untuk di berikan apresiasi dalam sikap dan sifat segan terhadap beliau oleh pegawai/karyawannya

3. Disarankan Kepada Kantor Urusan Agama Kecamatan Murung Kabupaten Murung Raya agar lebih mengedepankan pelayanan kerja secara maksimal terhadap masyarakat Murung Raya Khususnya di Lingkup Kecamatan Murung demi tercapainya masyarakat Murung Raya EMAS (Elok Mandiri Aman dan Sejahtera) seperti ikon yang telah di gaungkan selama ini yakni Murung Raya EMAS 2030. Serta kedepannya Kantor Urusan Agama Kecamatan Murung Kabupaten Murung Raya lebih menggutamakan programprogram kerja yang bersentuhan secara langsung dengan masyarakat.

\section{DAFTAR REFERENSI}

Ariyadi, Ariyadi. "Metodologi Istinbath Hukum Prof. Dr. Wahbah Az Zuhaili." Jurnal Hadratul Madaniyah 4.I (2017): 32-39.

\section{Rekomendasi}

1. Disarankan kepada Kepala Kantor Urusan Agama Kecamatan Murung Kabupaten Murung Raya lebih mengedepankan komunikasi yang intensif terhadap bawahanya agar segala program- program Kantor Urusan Agama Kecamatan Murung Kabupaten Murung Raya dapat berjalan secara efektif dan efisien sehingga segala tujuan program tersebut dapat tercapai dengan maksimal.

Martoyo, Susilo, Manajemen Sumber Daya Manusia, Bandung: PT. Remaja Rosdakarya, 2000

Moleong, Lexy J., Metodologi Pengamatan Kualitatif, cetakan ketujuh belas, Bandung: PT Remaja Rosdakarya, 2005

Harbani, Pasalong, Kepemimpinan Birokrasi. Bandung: Alfabeta, 2008

Siagian, Sondang P., Filsafat Administasi. Jakarta: Bumi Aksara, 2003

Winardi, Kepemimpinan Dalam Manajemen. Jakarta: Rineka Cipta, 2000

Asyarie Abbas dan Marwito, "Gaya Kepemimpinan Kepala Kantor Wilayah Kementerian Agama Provinsi Kalimantan Tengah”. Jurnal Ilmiah Magister Administrasi Publik Universitas Muhammadiyah Palangkaraya, Pencerah Publik Vol 2 Nomor I April Tahun 2015 